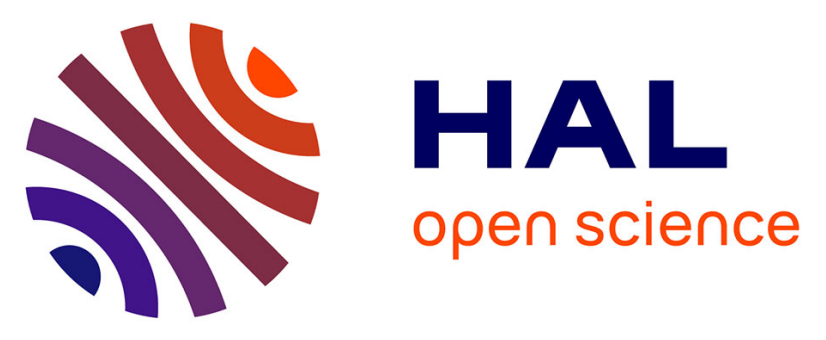

\title{
Prevalence and Clinical Patterns of Ocular Complications Associated With Anti-PD-1/PD-L1 Anticancer Immunotherapy
}

Karen Bitton, Jean-Marie Michot, Emmanuel Barreau, Olivier Lambotte, Oscar Haigh, Aurélien Marabelle, Anne-Laure Voisin, Christine Mateus, Anne-Laure Rémond, Chloé Couret, et al.

\section{To cite this version:}

Karen Bitton, Jean-Marie Michot, Emmanuel Barreau, Olivier Lambotte, Oscar Haigh, et al.. Prevalence and Clinical Patterns of Ocular Complications Associated With Anti-PD-1/PD-L1 Anticancer Immunotherapy. American Journal of Ophthalmology, 2019, 202, pp.109 - 117. 10.1016/j.ajo.2019.02.012 . hal-03485099

\section{HAL Id: hal-03485099 \\ https://hal.science/hal-03485099}

Submitted on 20 Dec 2021

HAL is a multi-disciplinary open access archive for the deposit and dissemination of scientific research documents, whether they are published or not. The documents may come from teaching and research institutions in France or abroad, or from public or private research centers.
L'archive ouverte pluridisciplinaire HAL, est destinée au dépôt et à la diffusion de documents scientifiques de niveau recherche, publiés ou non, émanant des établissements d'enseignement et de recherche français ou étrangers, des laboratoires publics ou privés.

\section{(ㄷ)(1) $\$$}

Distributed under a Creative Commons Attribution - NonCommerciall 4.0 International 
Prevalence and clinical patterns of ocular complications associated with anti-PD-

$$
\text { 1/PD-L1 anticancer immunotherapy }
$$

Short title: ocular complications of anticancer immunotherapy

Karen Bitton ${ }^{1,2}$, Jean-Marie Michot ${ }^{3}$, Emmanuel Barreau ${ }^{1}$, Olivier Lambotte, $2,4,5,6$, Oscar Haigh ${ }^{6}$, Aurélien Marabelle ${ }^{3,7}$, Anne-Laure Voisin ${ }^{8}$, Christine Mateus ${ }^{9}$, AnneLaure Rémond ${ }^{10}$, Chloé Couret ${ }^{11}$, Stéphane Champiat ${ }^{3}$, Marc Labetoulle ${ }^{1,2,5,6}$,

$$
\text { Antoine Rousseau }{ }^{1,2,5,6}
$$

1) Assistance Publique Hôpitaux de Paris, Hôpital Bicêtre, Service d'Ophtalmologie, DHU Vision \& Handicaps, Centre de référence pour les maladies rares en ophtalmologie (OPHTARA), F-94275, Le Kremlin-Bicêtre, France.

2) Université Paris-Sud, F-94276, Le Kremlin-Bicêtre, France.

3) Gustave Roussy, Université Paris-Saclay, Département d'Innovation Thérapeutique et d'Essais Précoces, Villejuif, F-94805, France.

4) Assistance Publique Hôpitaux de Paris, Hôpital Bicêtre, Service de Médecine Interne et Immunologie Clinique, F-94275, Le Kremlin-Bicêtre, France.

5) INSERM U1184, Immunology of Viral Infections and Autoimmune Diseases, F94276, Le Kremlin-Bicêtre, France.

6) CEA, DSV/iMETI, IDMIT, F-92265, Fontenay-aux-Roses, France Department of Immunology of viral and auto-immune disease, (IMVA/ IDMIT), UMR1184, CEA, Fontenay-aux-Roses.

7) INSERM U1015, Gustave Roussy, F-94800, Villejuif, France

8) Gustave Roussy, Université Paris Saclay, Unité Fonctionnelle de Pharmacovigilance, F-94800, Villejuif, France

9) Gustave Roussy, Université Paris-Saclay, Department of supportive care, F94800, Villejuif, France

10) Assistance Publique Hôpitaux de Paris, Hôpital Pitié-Salpétrière, Service d'Ophtalmologie, DHU Vision \& Handicaps, Centre de référence pour les maladies rares en ophtalmologie (OPHTARA), 75013, Paris, France.

11) $\mathrm{CHU}$ de Nantes, Service d'Ophtalmologie, 44093 Nantes

Manuscript word count: 2561

\section{Corresponding Author}

Antoine Rousseau, MD, Service d'Ophtalmologie, Hôpital de Bicêtre, 78, rue du

Général Leclerc, 94275 Le Kremlin Bicêtre. Phone: +33 1452127 99, Fax: +33 145

2122 46. Email: antoine.rousseau@aphp.fr. 


\section{Introduction}

In the last decade, the development of immune checkpoint inhibitors (ICls) has revolutionized the treatment of various advanced cancers. These drugs block inhibitory receptors of the immune system, thus enabling specific antitumor $\mathrm{T}$ cell responses. ICls include monoclonal antibodies directed against programmed death-1 receptor (PD-1), its ligand (PD-L1), and the cytotoxic $\mathrm{T}$ lymphocyte-associated antigen 4 (CTLA-4). Antibodies that interfere with the PD-(L)1 interaction show less toxicity than ipilimumab (CTLA-4-targeting) and are henceforth the most commonly used ICls, administered either alone or in combination with anti-CTLA-4. ${ }^{1,2}$ While initially given for metastatic malignant melanoma $(\mathrm{MM})$ and non-small cell lung carcinoma (NSCLC), indications for anti-PD-(L)1 have recently been extended to treat renal cell carcinoma, head and neck squamous cell carcinoma, and Hodgkin's lymphoma.

The PD-1 signaling pathway plays a central role in maintaining peripheral tolerance and down-regulating antigen-specific T-cell activation, immunity, and immunemediated inflammatory disease. When bound by its ligands, PD-L1 and PD-L2, PD-1 inhibits T-cell activation and limits immune effector responses. ${ }^{3}$ Tumors can express PD-L1 as one mechanism of inhibiting antitumor T-cell-mediated responses in the tumor microenvironment. Blockade of this receptor/ligand interaction with anti-PD-1 monoclonal antibodies, such as pembrolizumab and nivolumab, or anti-PD-L1 atezolizumab, durvalumab and avelumab increases the immune response against tumor cells.

By the same mechanism, anti-PD-(L)1 can override the suppression of self-targeting immune responses to generate immune-related adverse events (irAEs). The most common irAEs affect the skin (pruritus, rash and vitiligo), the digestive tract (colitis and hepatitis), and endocrine tissues (mainly thyroiditis), in approximately $20 \%$ of 
patients. ${ }^{1,2}$ Less frequently, irAEs affect lungs, kidneys, or the nervous system. ${ }^{2}$ Ophthalmic irAEs, mainly dry eye disease, were reported in early clinical trials. ${ }^{4}$ Since then, few small case series have reported incidents of intraocular or orbital inflammation. .-20 Yet, the prevalence of these complications among anti PD-(L)1treated patients has not yet been determined. As ocular irAEs may threaten visual function $^{20}$ and lead to severe deterioration of the quality of life of patients, further investigation is warranted, and described herein. Using a prospective cohort of ICltreated patients, we determined the prevalence and the incidence of ocular complications following anti-PD-(L)1 treatment. Furthermore, we studied individual cases reported through a national pharmacovigilance registry of ICI-treated patients. We discuss the clinical patterns in our case series and those reported in the literature and the putative underlying pathophysiological mechanisms.

\section{Patients and methods}

This non-interventional study reports the ocular complications associated with antiPD-1/PD-L1 collected through i) a single-center prospective cohort and ii) a declarative pharmacovigilance registry, which are merged into the REISAMIC registry (Registre des Effets Indésirables Sévères des Anticorps Monoclonaux Immunomodulateurs en Cancérologie). The study protocol was approved by the Ethics Committee of the French Society of Ophthalmology (IRB 00008855 Société Française d'Ophtalmologie IRB\#1).

REISAMIC is a pharmacovigilance registry of irAE in ICl-treated patients, set up at the Gustave Roussy Cancer Centre (Villejuif, France). Only irAE of grade $\geq 2$ (i.e. requiring moderate local noninvasive intervention), according to the Common Terminology Criteria for Adverse Events (CTCAE) $)^{21}$ are included in REISAMIC. REISAMIC is based on i) a single-centre prospective cohort (initiated in June 2014 at 
Gustave Roussy cancer centre) for patients treated in 'real-life' situations, i.e. following marketing authorisation, as part of patient access programmes for unlicensed medications or during compassionate use, and ii) a national pharmacovigilance registry of irAEs occurring in ICl-treated patients. A reference network of organ specialists reviews every irAE declared in REISAMIC during bimonthly multidisciplinary meetings. ${ }^{22}$ Since 2016 the registry is accessible via a mobile application in order to collect irAE data more efficiently. In the present study, we focused on patients with ocular irAE grade $\geq 2$ following anti-PD-(L)1 immunotherapy to treat malignancy that were included in the REISAMIC registry between June $1^{\text {st }} 2014$, and March $1^{\text {st }} 2018$.

\section{Data collection}

For individual patients, cancer history and disease evolution, treatments received, and all irAEs were recorded. There was no systematic ophthalmologic examination planned in the prospective cohort. Consequently, patients of both the prospective cohort and the declarative registry were referred to the ophthalmology department in any case of ophthalmic complaints. In this case, patients underwent comprehensive ophthalmologic assessment by a trained ophthalmologist that included physical examination, and ocular and/or orbital imaging at the discretion of the clinician. Intraocular inflammation was graded according to the Standardization Uveitis Nomenclature Group (SUN) criteria. ${ }^{23}$ The severity of adverse events was graded according to the CTCAE version 5.0. ${ }^{21}$ Tumoral response to $\mathrm{ICI}$ was classified according to revised RECIST guideline (version 1.1). ${ }^{24}$ This non-interventional study was conducted in compliance with good clinical practice and the tenets of the Declaration of Helsinki. Constitution of the REISAMIC registry had been authorized by the French National Data Protection Commission (Commission Nationale de I'Informatique et des Libertés). 


\section{Statistical analysis}

Patient anonymity was maintained throughout the data collection and statistical analysis phases. Descriptive statistical analysis was performed with Excel for Mac (version 15.16). We estimated the prevalence of ocular complications associated with anti-PD-1/PD-L1 anti-cancer immunotherapy from the prospective patient cohort of the REISAMIC registry alone. We also estimated the incidence of irAEs per patientmonths of anti-PD-(L)1 treatment. The cumulative duration of treatment received by all the patients of the prospective cohort has been calculated as follows: ((date of the last infusion or $03 / 01 / 2018$ )-(date of first infusion)/30.5), where the date $03 / 01 / 2018$ is the end of the inclusion period, and 30.5 is the average number of days per month. Regarding patients who received a single infusion of treatment, and to avoid their de facto exclusion of analysis, we used the value of 0.75 for patients treated with pembrolizumab or atezolizumab (infusion every three weeks), or 0.5 for patients treated with nivolumab (infusion every two weeks).

\section{Results}

\section{Frequency of ocular complications and systemic characteristics of patients}

Of a total of 745 patients treated with anti-PD-(L)1 included in the prospective cohort during the study period, three were reported as having ocular irAEs, providing a prevalence of anti-PD-(L)1-associated moderate to severe ocular irAEs of 4/1000. Altogether, patients of the prospective cohort were exposed to a total duration of treatment of 4277.4 months. Therefore, the incidence of anti-PD-(L)1-associated moderate to severe ocular irAEs was 0.7 per 1000 patient-months.

An additional five anti-PD-(L)1-treated patients with moderate to severe ocular irAEs were concomitantly declared to the national pharmacovigilance registry, and were reviewed by the reference network ophthalmologist (EB). 
When taking all these 8 cases into account, six patients (75\%) had received anti-PD1 monotherapy, two anti-CTLA-4 therapy (ipilimumab, which had been stopped 5 and 46 months earlier), one patient anti-PD-1 as well as anti-CTLA-4 immunotherapy, and the $8^{\text {th }}$ patient anti-PD-L1 (atezolizumab). Three patients had non-small cell lung cancer (NSCLC), two cutaneous melanoma, one adenoid cystic carcinoma of the parotid gland, one mesothelioma, and one clear cell renal cell carcinoma (Table 1). Five patients (62.5\%) experienced an additional extra-ophthalmological irAE. At the end of the follow-up, all patients were considered to respond to the $\mathrm{ICI}$ treatment, with four patients being partial responders, three presenting with stable disease, and one complete responder.

Ocular irAEs occurred after the second infusion in half of the patients, but could occur at anytime up to the $36^{\text {th }}$ infusion. Ocular irAEs occurred during the treatment or after cessation of the treatment (which could be motivated by cancer remission or serious systemic adverse events). The median time of ocular irAEs occurrence was 29 days \pm 41 (range: $1-120$ days) after an infusion of treatment.

\section{Ophthalmological features}

Ocular irAEs consisted of ocular surface disease $(n=2)$, intraocular $(n=5)$ and orbital inflammation $(n=1)$. The CTCAE grades of severity were grade $2(4 / 8)$ and grade 3 (4/8). Anti-PD-(L)1 were discontinued in 6/8 patients. In these 6 patients, reason of discontinuation was ocular irAEs in $4 / 6$ patients (in case $\# 7$, discontinuation was motivated by concomitant ocular and systemic adverse events); cancer remission in 1 patient (case\#4) and extraocular irAE in one patient (i.e. peripheral neuropathy, case\#1). Two patients continued ICI treatment despite ocular complications (case \#2 and case \#8). At the final visit, 4/8 patients had complete resolution of ocular irAEs and $4 / 8$ patients were controlled by treatments. The mean follow-up period was 5.1 months (Table 2). Illustrative case reports and video are 
provided in supplemental materials.

\section{Discussion}

Using a prospective $\mathrm{ICl}$-treated patient cohort we were able to robustly determine that the prevalence of moderate to severe ocular manifestations associated with antiPD-(L)1 anticancer immunotherapy was $0.4 \%$ and the incidence was 0.7 per 1000 patient-months of treatment. Furthermore, data collected through a national pharmacovigilance registry illustrated distinct clinical patterns, including intraocular inflammation, ocular surface inflammation, and orbital neuromuscular disorders that may occur in anti-PD-(L)1 treated patients.

\section{Intraocular inflammation}

A few case reports, and short series reported intraocular inflammation associated with anti-PD-(L)1 therapies. ${ }^{5,7-9,11,13,17,18}$ The spectrum ranged from anterior uveitis, usually non-granulomatous and of variable severity, $, 8,11,18$ to panuveitis which may have various non-specific features including vitritis, retinal vasculitis, papilitis, retinal serous detachment, chorio-retinal lesions ${ }^{5,7,9,17,25}$, and even uveal effusion. ${ }^{20}$ More generally, uveitis may occur in the context of ICl-associated systemic diseases, such as sarcoidosis 26,27 as in case \#4. Therefore, systemic work-up may be performed in all patients, both to exclude a differential diagnosis and to look for immune-related systemic conditions.

The prevalence of anti-PD-1-associated symptomatic intraocular inflammation was $0.2 \%$ in our current study, which was slightly inferior to that published in a recent systematic review about ocular manifestations of ICls $(0.3 \%-0.6 \%) .{ }^{28}$ However, this complete review included patients receiving anti-CTLA-4 treatment, known to induce irAEs more frequently. ${ }^{2}$ Thomas et. al., recently hypothesized that intraocular inflammation from ICls could stem from reprogramming of the cell death pathway in 
an immune-privileged tissue. ${ }^{20}$ This hypothesis is supported by a case of corneal graft rejection in a patient treated with nivolumab for primary lung cancer. ${ }^{29}$ Intraocular inflammation associated with anti-PD-(L)1 can be controlled with topical steroids. However, severe inflammation and posterior segment involvement may require systemic treatment. ${ }^{9}$ Diem et. al., recently suggested that uveitis secondary to pembrolizumab, as well as other irAES such as vitiligo, could be surrogate markers for a beneficial MM treatment response. ${ }^{30}$ Similarly, in our series, we found that the two pembrolizumab-treated MM patients presenting with uveitis had positive best overall antitumor responses after treatment.

\section{Ocular surface diseases}

Dry eye disease (DED) was the first and initially the most frequently reported ocular side effect in $\mathrm{ICl}$-treated patients. In one of the first Phase 1 studies published on anti-PD-(L)1 safety, up to $1 \%$ of patients developed dry eye while receiving treatment

.${ }^{4}$ Dry eye has also been described as a common complication of all ICI treatments in a recent review. ${ }^{25}$ Ocular surface diseases, such as episcleritis and blepharitis have been included in the detailed recommendations for management of $\mathrm{ICl}$ adverse effects by the American Society of Clinical Oncology. ${ }^{31}$ The peculiar feature of patient \#8 was 1) the severity of dry eye, which required specific interventions, and 2) the chronology of symptoms that were exacerbated after infusions. For these reasons, we included patient \#8 in this study. However, prevalence of anti-PD-(L)1-induced DED may be difficult to assess due to association with other medications, ${ }^{32}$ and due to difficulties in the reporting criteria for DED. ${ }^{33}$ Altogether, these issues may contribute to under-reporting of this condition, and more study will be required to determine the connection between ICI and DED. Moreover, anti-PD-(L)1 therapy may induce sicca syndrome as part of a systemic disease like Sjögren's syndrome, ${ }^{27,34}$ or sarcoidosis. ${ }^{35}$ Dry eye may also be due to meibomian gland dysfunction arising from 
anti-PD-1-induced ocular rosacea. ${ }^{36}$ Experimental data suggests that downregulation of corneal epithelial PD-(L)1 amplifies DED-associated corneal inflammation and epitheliopathy. ${ }^{37}$ Although DED is in most cases not a blinding condition, it can be associated with severe reduction in quality of life. ${ }^{38}$ Case \#6 developed DED in the context of lichen planus induced by ICls. Thus, DED in this case was associated with lesions of cicatrizing conjunctivitis, a complication of involving the basement membrane of the mucosal epithelia. ${ }^{39}$

\section{Orbital neuromuscular manifestations}

Anti-PD-(L)1 may induce orbital myasthenia gravis and myositis. ${ }^{40,41}$ Interestingly, we found two reported cases of ophthalmoplegia concomitant with myocarditis associated with anti-PD-1.14, 42 Both cases were treated with intravenous immunoglobulins and high dose intravenous corticosteroid. Anti-acetylcholine receptor and myositis-associated antibodies were both negative. MRI utilised by Nasr et al., confirmed the diagnosis of myositis of the ocular muscles. ${ }^{14}$ Touat et al., reported the clinicopathological features of ten patients with myositis during anti-PD(L)1 therapy. ${ }^{43}$ Electrodiagnostic studies highlighted a myopathic process without decrement pattern, while anti-acetylcholine receptor and myositis-associated antibodies were negative. Interestingly, Suzuki et al., recently reported a series of anti-PD-(L)1-treated patients with concomitant myasthenia gravis and myositis. Some patients had positive anti-acetylcholine antibodies and concomitant myocarditis. ${ }^{41}$ Adverse events including diplopia and/or oculomotor paralysis occurring in patients under ICls should be considered with the greatest precaution, as these conditions can be associated with life-threatening myocarditis.

\section{Management and evolution of ocular irAEs}

Most ocular side effects of ICls are managed with topical or periocular corticosteroids, but advanced cases may require systemic corticosteroids and 
cessation of checkpoint inhibitor therapy. ${ }^{25}$ In this study, most patients were treated with topical corticosteroids (7/8) and/or systemic corticosteroid (3/8) with resolution of the symptoms. Two patients required increasing doses of corticosteroid or immunomodulatory agents because of the severity of the situation. In this study, there were no prospectively defined criteria for stopping ICI treatment in response to ocular complications. Continuation or discontinuation of treatment was evaluated on a case by case basis, based on the severity and the response to ophthalmological treatment. However, detailed recommendations for management of irAEs have been recently published. ${ }^{31}$ In summary, for moderate (CTCAE grade 2, such as anterior uveitis) toxicities, ICI should be held until symptoms revert to grade 1 levels or lower and corticosteroids may be offered. For severe (grade 3, such as posterior uveitis) toxicity, patients should receive systemic corticosteroids. Restarting immunotherapy after a grade 3 toxicity requires extreme precaution. These recommendations include specific recommendations for episcleritis, uveitis and blepharitis but do not address other possible ocular manifestations.

In addition to the variability of the ocular symptoms, the time of onset was variable: symptoms could occur from one day after the second infusion, and after the $36^{\text {th }}$ infusion. However, half of the patients developed symptoms after their $2^{\text {nd }}$ cycle, i.e. during the early treatment phase.

Limitations of our study included the potential role of other medications in the occurrence of ocular side effects. ${ }^{44}$ Anti-CTLA-4 are known to be associated with ocular inflammatory side effects. ${ }^{6,28}$ However, only one patient had concomitant antiCTLA-4 treatment, and for patients with previous anti-CTLA-4, the chronology of ocular pathology was in favor of anti-PD-(L)1-induced ocular manifestations. Besides, our series may not encompass the whole spectrum of anti-PD-(L)1-associated ocular complications which are rare and pleomorphic, but provides specific data 
complementary to those published in a recent comprehensive review on IClsassociated ocular complications. ${ }^{6,25}$ Finally, the REISAMIC prospective cohort is based on a declarative process. Some mild ocular manifestations may have been overlooked, as ophthalmologic examination was performed only when a patient complained.

To summarize, based on robust epidemiologic data, the prevalence of moderate to severe ocular complications associated with anti-PD-(L)1 can be estimated at $0.4 \%$. Furthermore, anti-PD-(L)1 immunotherapy may be associated with a wide range of orbital/ocular inflammatory complications. The latter may be sight-threatening and/or associated with life-threatening conditions. As ICl treatments are being approved for an increasing number of indications, clinicians should be aware of these complications. Patients complaining of eye problems while receiving $\mathrm{ICl}$ treatment should immediately be seen by an ophthalmologist.

Supplemental data: illustrative case reports (case \#2, \#6, \#7).

Supplemental video: anti-PD-1-associated orbitopathy (Case \#7). Oculomotor test demonstrating a complete left ophthalmoplegia with ptosis, partial left ophthalmoplegia with complete deficient adduction (reproduced with written consent of the patient). 


\section{Acknowledgements}

\section{1) Funding / support}

This study received no funding.

\section{2) Financial disclosure}

Dr. Bitton has nothing to disclose.

Dr. Michot has nothing to disclose.

Dr. Barreau has nothing to disclose.

Dr. Lambotte is a consultant for MSD, BMS, Astra Zeneca, and has been an occasional consultant on subjects outside the scope of this work for LFB, Janssen, and CSL Behring.

Dr. Haigh has nothing to disclose.

Dr. Marabelle has nothing to disclose.

Dr. Voisin has nothing to disclose.

Dr. Mateus has nothing to disclose.

Dr. Rémond has nothing to disclose.

Dr. Couret has nothing to disclose.

Dr. Champiat has received honoraria from AstraZeneca, BMS, Janssen, MSD, Novartis and Roche.

Dr. Labetoulle has been an occasional consultant on subjects outside the scope of this work for Alcon, Allergan, Baush and Lomb, Dompe, Horus, MSD, Novartis, Santen, Shire, and Thea.

Dr. Rousseau has been an occasional consultant on subjects outside the scope of this work for Novartis, Allergan, Pfizer, Shire and Thea.

\section{3) Other acknowledgments}

The authors would like to acknowledge Dr. Farida Benoudiba (Department of Neuroradiology, Bicêtre Hopital) for interpretation of orbital imaging studies. 


\section{References}

1. Boutros C, Tarhini A, Routier E, et al. Safety profiles of anti-CTLA-4 and anti-PD-1 antibodies alone and in combination. Nat Rev Clin Oncol 2016; 13 (8):47386.

2. Michot JM, Bigenwald C, Champiat S, et al. Immune-related adverse events with immune checkpoint blockade: a comprehensive review. Eur J Cancer 2016; 54:139-148.

3. Blank CU. The perspective of immunotherapy: new molecules and new mechanisms of action in immune modulation. Curr Opin Oncol. 2014; 26 (2):204-14.

4. Brahmer JR, Tykodi SS, Chow LQ, et al. Safety and activity of anti-PD-L1 antibody in patients with advanced cancer. N Engl J Med. 2012; 366 (26):2455-65.

5. Abu Samra K, Valdes-Navarro M, Lee S, Swan R, Foster CS, Anesi SD. A case of bilateral uveitis and papillitis in a patient treated with pembrolizumab. Eur $\mathrm{J}$ Ophthalmol. 2016; 26 (3):e46-8.

6. Antoun J, Titah C, Cochereau I. Ocular and orbital side-effects of checkpoint inhibitors: a review article. Curr Opin Oncol. 2016; 28 (4):288-94.

7. Arai T, Harada K, Usui Y, Irisawa R, Tsuboi R. Case of acute anterior uveitis and Vogt-Koyanagi-Harada syndrome-like eruptions induced by nivolumab in a melanoma patient. J Dermatol. 2017; 44 (8):975-976.

8. Basilious A, Lloyd JC. Posterior subcapsular cataracts and hypotony secondary to severe pembrolizumab induced uveitis: Case report. Can J Ophthalmol 2016; 51 (1):e4-6.

9. Conrady CD, Larochelle M, Pecen P, Palestine A, Shakoor A, Singh A. Checkpoint inhibitor-induced uveitis: a case series. Graefes Arch Clin and Exp Ophthalmol 2018; 256 (1):187-191.

10. Hanna KS. A Rare Case of Pembrolizumab-Induced Uveitis in a Patient with Metastatic Melanoma. Pharmacotherapy 2016; 36 (11):e183-e188.

11. Kanno H, Ishida K, Yamada W, et al. Uveitis induced by programmed cell death protein 1 inhibitor therapy with nivolumab in metastatic melanoma patient. J Infect Chemother 2017; 23 (11):774-777.

12. Karlin J, Gentzler R, Golen J. Bilateral Anterior Uveitis Associated with Nivolumab Therapy. Ocular Immunol Inflamm 2018; 26 (2):283-285.

13. Manusow JS, Khoja L, Pesin N, Joshua AM, Mandelcorn ED. Retinal vasculitis and ocular vitreous metastasis following complete response to PD-1 inhibition in a patient with metastatic cutaneous melanoma. J Immunotherapy Cancer 2014; 2 (1):41.

14. Nasr F, El Rassy E, Maalouf G, et al. Severe ophthalmoplegia and myocarditis following the administration of pembrolizumab. Eur J Cancer 2018; 91:171-173.

15. Reddy M, Chen JJ, Kalevar A, Terribilini R, Agarwal A. IMMUNE RETINOPATHY ASSOCIATED WITH NIVOLUMAB ADMINISTRATION FOR METASTATIC NON-SMALL CELL LUNG CANCER. Retin Cases Brief Rep 2017.

16. Richardson DR, Ellis B, Mehmi I, Leys M. Bilateral uveitis associated with nivolumab therapy for metastatic melanoma: a case report. Int J Ophthalmol 2017; 10 (7):1183-1186.

17. Roberts P, Fishman GA, Joshi K, Jampol LM. Chorioretinal Lesions in a Case of Melanoma-Associated Retinopathy Treated With Pembrolizumab. JAMA Ophthalmol 2016; 134 (10):1184-1188.

18. Taylor SC, Hrisomalos F, Linette GP, Rao PK. A case of recurrent bilateral uveitis independently associated with dabrafenib and pembrolizumab therapy. Am Journal Ophthalmol Case Rep 2016; 2:23-25. 
19. Theillac C, Straub M, Breton AL, Thomas L, Dalle S. Bilateral uveitis and macular edema induced by Nivolumab: a case report. BMC Ophthalmol 2017; 17 (1):227.

20. Thomas M, Armenti ST, Ayres MB, Demirci H. Uveal Effusion After Immune Checkpoint Inhibitor Therapy. JAMA Ophthalmol 2018; 136 (5):553-556.

21. NIH. Common Terminology Criteria for Adverse Events, 2017.

22. Champiat S, Lambotte O, Barreau E, et al. Management of immune checkpoint blockade dysimmune toxicities: a collaborative position paper. Ann Oncol 2016; 27 (4):559-74.

23. Jabs DA, Nussenblatt RB, Rosenbaum JT. Standardization of uveitis nomenclature for reporting clinical data. Results of the First International Workshop. Am J Ophthalmol 2005; 140 (3):509-16.

24. Eisenhauer EA, Therasse $P$, Bogaerts $J$, et al. New response evaluation criteria in solid tumours: revised RECIST guideline (version 1.1). Eur J Cancer 2009; 45 (2):228-47.

25. Dalvin LA, Shields CL, Orloff $M$, Sato T, Shields JA. CHECKPOINT INHIBITOR IMMUNE THERAPY: Systemic Indications and Ophthalmic Side Effects. Retina 2018; 38 (6):1063-1078.

26. Cousin $\mathrm{S}$, Toulmonde $\mathrm{M}$, Kind $\mathrm{M}$, et al. Pulmonary sarcoidosis induced by the anti-PD1 monoclonal antibody pembrolizumab. Ann Oncol 2016; 27 (6):1178-9.

27. Le Burel S, Champiat S, Mateus C, et al. Prevalence of immune-related systemic adverse events in patients treated with anti-Programmed cell Death 1/antiProgrammed cell Death-Ligand 1 agents: A single-centre pharmacovigilance database analysis. Eur J Cancer 2017; 82:34-44.

28. Abdel-Rahman $\mathrm{O}$, Oweira $\mathrm{H}$, Petrausch $\mathrm{U}$, et al. Immune-related ocular toxicities in solid tumor patients treated with immune checkpoint inhibitors: a systematic review. Expert Rev of Anticancer Ther 2017; 17 (4):387-394.

29. Le Fournis S, Gohier P, Urban T, Jeanfaivre T, Hureaux J. Corneal graft rejection in a patient treated with nivolumab for primary lung cancer. Lung Cancer 2016; 102:28-29.

30. Diem S, Keller F, Ruesch R, et al. Pembrolizumab-triggered Uveitis: An Additional Surrogate Marker for Responders in Melanoma Immunotherapy? J Immunother 2016; 39 (9):379-382.

31. Brahmer JR, Lacchetti C, Schneider BJ, et al. Management of ImmuneRelated Adverse Events in Patients Treated With Immune Checkpoint Inhibitor Therapy: American Society of Clinical Oncology Clinical Practice Guideline. J Clin Oncol 2018; 36 (17):1714-1768.

32. Gomes JAP, Azar DT, Baudouin C, et al. TFOS DEWS II iatrogenic report. Ocul Surf 2017; 15 (3):511-538.

33. Stapleton F, Alves M, Bunya VY, et al. TFOS DEWS II Epidemiology Report. Ocul Surf 2017; 15 (3):334-365.

34. Cappelli LC, Gutierrez AK, Baer AN, et al. Inflammatory arthritis and sicca syndrome induced by nivolumab and ipilimumab. Ann Rheum Dis 2017; 76 (1):43-50. 35. Montaudie H, Pradelli J, Passeron T, Lacour JP, Leroy S. Pulmonary sarcoidlike granulomatosis induced by nivolumab. Br J Dermatol 2017; 176 (4):1060-1063.

36. Brouwer NJ, Haanen J, Jager MJ. Development of Ocular Rosacea following Combined Ipilimumab and Nivolumab Treatment for Metastatic Malignant Skin Melanoma. Ocul Oncol Pathol 2017; 3 (3):188-192.

37. El Annan J, Goyal S, Zhang Q, Freeman GJ, Sharpe AH, Dana R. Regulation of T-cell chemotaxis by programmed death-ligand 1 (PD-L1) in dry eye-associated corneal inflammation. Invest Ophthalmol Vis Sci 2010; 51 (7):3418-23. 
38. Labetoulle M, Rolando M, Baudouin C, van Setten G. Patients' perception of DED and its relation with time to diagnosis and quality of life: an international and multilingual survey. Br J Ophthalmol 2017; 101 (8):1100-1105.

39. Thorne JE, Jabs DA, Nikolskaia OV, Mimouni D, Anhalt GJ, Nousari HC. Lichen planus and cicatrizing conjunctivitis: characterization of five cases. Am J Ophthalmol 2003; 136 (2):239-43.

40. Makarious D, Horwood K, Coward JIG. Myasthenia gravis: An emerging toxicity of immune checkpoint inhibitors. Eur J Cancer 2017; 82:128-136.

41. Suzuki S, Ishikawa N, Konoeda F, et al. Nivolumab-related myasthenia gravis with myositis and myocarditis in Japan. Neurology 2017; 89 (11):1127-1134.

42. Alnabulsi $R$, Hussain A, DeAngelis D. Complete ophthalmoplegia in Ipilmumab and Nivolumab combination treatment for metastatic melanoma. Orbit 2018:1-4.

43. Touat M, Maisonobe T, Knauss S, et al. Immune checkpoint inhibitor-related myositis and myocarditis in patients with cancer. Neurology 2018; 91 (10):e985-e994. 44. Rousseau A, Labetoulle M. [Recently recognized ophthalmic complications of systemic treatments]. J Fr Ophtalmol 2015; 38 (9):876-82. 
Tables:

\begin{tabular}{|c|c|c|c|c|c|c|}
\hline Case \# & Age / gender & Cancer & $\begin{array}{l}\text { Previous anticancer } \\
\text { treatments }\end{array}$ & Anti-PD-(L)1 & $\begin{array}{l}\text { Systemic Anti-PD-(L)1 } \\
\text { associated } \\
\text { complications }\end{array}$ & $\begin{array}{l}\text { Best Overall } \\
\text { anti-tumoral } \\
\text { Response } \\
\text { with ICI }\end{array}$ \\
\hline 1 & $77 / \mathrm{M}$ & mesothelioma & carboplatine, pemetrexed & $\begin{array}{c}\text { nivolumab (combined with } \\
\text { ipilimumab) }\end{array}$ & $\begin{array}{l}\text { peripheral neuropathy, } \\
\text { lower limbs edema }\end{array}$ & PR \\
\hline 2 & $63 / F$ & NSCLC & none & nivolumab & none & PR \\
\hline 3 & $44 / F$ & $\mathrm{MM}$ & dacarbazine & pembrolizumab & vitiligo, hepatitis & SD \\
\hline 4 & $71 / F$ & MM & dacarbazine, vemurafenib & pembrolizumab & systemic sarcoidosis & PR \\
\hline 5 & $56 / F$ & CCRCC & sunitinib & nivolumab & none & SD \\
\hline 6 & $57 / F$ & $\begin{array}{c}\text { parotid } \\
\text { adenocarcinoma }\end{array}$ & $\begin{array}{c}\text { cyclophosphamide, epirubicine, } \\
\text { 5-fluorouracil, docetaxel, } \\
\text { létrozole, trastuzumab, } \\
\text { vinorelbine }\end{array}$ & atezolizumab & lichen planus & SD \\
\hline 7 & $80 / \mathrm{M}$ & NSCLC & none & pembrolizumab & myocarditis & $\mathrm{CR}$ \\
\hline 8 & $70 / \mathrm{M}$ & $\begin{array}{c}\text { lung } \\
\text { adenocarcinoma }\end{array}$ & none & pembrolizumab & none & PR \\
\hline
\end{tabular}

Table 1: Systemic data. $\mathrm{M}=$ male, $\mathrm{F}=$ female, $\mathrm{NSCLC}=$ Non small cell lung carcinoma, $\mathrm{MM}=$ malignant melanoma, $\mathrm{CCRCC}=$ clear cell renal cell carcinoma, $\mathrm{ICl}=$ immune checkpoint inhibitor, $\mathrm{PR}=$ partial remission, $\mathrm{SD}=$ stable disease, $\mathrm{CR}=$ complete remission. Rows highlighted in grey correspond to the cases from the prospective cohort. 


\begin{tabular}{|c|c|c|c|c|c|c|c|c|c|c|c|}
\hline Case \# & $\begin{array}{l}\text { Number } \\
\text { of } \\
\text { infusion } \\
\text { before } \\
\text { onset }\end{array}$ & $\begin{array}{l}\text { Delay of } \\
\text { onset } \\
\text { after } \\
\text { infusion } \\
\text { (days) }\end{array}$ & $\begin{array}{l}\text { Ongoing ICI } \\
\text { treatment } \\
\text { when the } \\
\text { ocular } \\
\text { complication } \\
\text { occurred } \\
\text { (yes / no) }\end{array}$ & $\begin{array}{l}\text { Ocular anti-PD-(L)1 associated } \\
\text { complications }\end{array}$ & $\begin{array}{l}\text { CTCAE } \\
\text { grade }\end{array}$ & Treatment & $\begin{array}{l}\text { Ophthalmological } \\
\text { Follow-up } \\
\text { (months) }\end{array}$ & $\begin{array}{l}\text { Outcome of } \\
\text { ocular irAE }\end{array}$ & $\begin{array}{c}\text { Continuation } \\
\text { of ICl } \\
\text { treatment }\end{array}$ & $\begin{array}{l}\text { Reason for ICI } \\
\text { discontinuation }\end{array}$ & $\begin{array}{l}\text { ICI } \\
\text { discontinuation } \\
\text { for ocular } \\
\text { manifestation } \\
\text { (yes / no) }\end{array}$ \\
\hline 1 & 2 & 21 & yes & $\begin{array}{l}\text { bilateral chemosis and nongranulomatous } \\
\text { anterior uveitis ( } 1+\text { cell in both eyes), no } \\
\text { posterior synechiae }\end{array}$ & 2 & $\begin{array}{l}\text { topical DXM ( } 5 \text { drops/day with } \\
\text { tapering over } 4 \text { weeks) }\end{array}$ & 3 & resolution & no & $\begin{array}{l}\text { extra ocular } \\
\text { manifestation } \\
\text { (peripheral } \\
\text { neuropathy) }\end{array}$ & no \\
\hline 2 & 36 & 14 & yes & $\begin{array}{c}\text { bilateral panuveitis including } \\
\text { nongranulomatous anterior chamber } \\
\text { inflammation (with cyclitic membrane, } \\
\text { Descemet's folds, } 3+\text { cell and flare and } \\
\text { posterior synechiae in the RE; } 1+\text { cell and } \\
\text { flare in the LE), } 1+\text { bilateral vitritis, papillitis, } \\
\text { choroidal infiltrates }\end{array}$ & 3 & $\begin{array}{l}\text { topical DXM (8 drops/day with } \\
\text { tapering over } 4 \text { weeks in the } \\
\text { RE, } 6 \text { drops/day with tapering } \\
\text { over } 4 \text { weeks in the LE) + } 5 \\
\text { DXM subconjunctival } \\
\text { injections in the RE }\end{array}$ & 1 & controlled & yes & NA & NA \\
\hline 3 & 18 & 3 & yes & $\begin{array}{c}\text { bilateral nongranulomatous anterior uveitis } \\
(1+\text { cell in both eyes }), \text { no posterior synechiae }\end{array}$ & 2 & $\begin{array}{c}\text { topical DXM ( } 6 \text { drops/day with } \\
\text { tapering over } 4 \text { weeks) }\end{array}$ & 2 & resolution & no & $\begin{array}{l}\text { ocular } \\
\text { manifestation }\end{array}$ & yes \\
\hline 4 & 8 & 120 & no & $\begin{array}{l}\text { bilateral nongranulomatous anterior uveitis } \\
\text { (1+ cell in both eyes), no posterior synechiae }\end{array}$ & 2 & $\begin{array}{l}\text { topical DXM ( } 6 \text { drops/day with } \\
\text { tapering over } 4 \text { weeks) }\end{array}$ & 7 & resolution & no & $\begin{array}{l}\text { cancer } \\
\text { remission }\end{array}$ & no \\
\hline 5 & 2 & 15 & yes & $\begin{array}{c}\text { bilateral panuveitis with nongranulomatous } \\
\text { anterior chamber inflammation (2+ cell and } \\
\text { flare in both eyes), } 1+\text { bilateral vitritis, bilateral } \\
\text { serous retinal detachment, infero-macular } \\
\text { retinal pigment epithelial detachment in the } \\
\text { left eye }\end{array}$ & 3 & $\begin{array}{l}\text { systemic CS (IV } \\
\text { methylprednisolone } 500 \mathrm{mg} / \\
\text { day for } 3 \text { days followed by } \\
\text { prednisone } 1 \mathrm{mg} / \mathrm{kg} \text { with } \\
\text { tapering over } 3 \text { months })+ \\
\text { topical DXM ( } 6 \text { drops/day with } \\
\text { tapering over } 4 \text { weeks) }\end{array}$ & 9 & $\begin{array}{l}\text { initial } \\
\text { improvement } \\
\text { with relapse } \\
\text { on re- } \\
\text { challenge }\end{array}$ & no & $\begin{array}{c}\text { ocular } \\
\text { manifestation }\end{array}$ & yes \\
\hline 6 & 10 & 60 & yes & $\begin{array}{c}\text { bilateral cicatrizing conjunctivitis with bilateral } \\
\text { Oxford grade } 4 \text { SPK, bilateral inferior fornix } \\
\text { shortening + upper and lower tarsal } \\
\text { conjunctival fibrosis, Schirmer test }<5 \mathrm{~mm} \text { in } \\
\text { both eyes }\end{array}$ & 3 & $\begin{array}{c}\text { topical DXM (4 drops/day) / } \\
\text { systemic CS (prednisone } \\
15 \mathrm{mg} \text { ongoing) + scleral lens }\end{array}$ & 7 & controlled & no & $\begin{array}{c}\text { ocular } \\
\text { manifestation }\end{array}$ & yes \\
\hline 7 & 2 & 1 & yes & $\begin{array}{c}\text { bilateral orbital myositis, with bilateral ptosis } \\
\text { and complete left ophthalmoplegia, right } \\
\text { limitation of adduction. }\end{array}$ & 3 & $\begin{array}{c}\text { systemic CS }(1 \mathrm{mg} / \mathrm{kg})+\text { IVIG } \\
(2 \mathrm{~g} / \mathrm{kg})+\text { methotrexate } \\
(15 \mathrm{mg} / \text { week })\end{array}$ & 6 & resolution & no & $\begin{array}{l}\text { ocular and } \\
\text { cardiac } \\
\text { manifestations }\end{array}$ & yes \\
\hline 8 & 2 & 1 & yes & $\begin{array}{l}\text { bilateral severe dry eye disease with Oxford } \\
\text { grade } 3 \mathrm{SPK} \text {, Schirmer test }<5 \mathrm{~mm} \text {, in both } \\
\text { eyes }\end{array}$ & 2 & $\begin{array}{l}\text { topical CS ( } 3 \text { drops/day) / } \\
\text { punctal plugs }\end{array}$ & 6 & controlled & yes & NA & NA \\
\hline
\end{tabular}


Table 2: Anti-PD-(L)1 associated ocular complications. CTCAE = Common Terminology Criteria for Adverse Events, irAE = immune related adverse effect, $\mathrm{NA}=$ non applicable, $\mathrm{CS}=$ corticosteroid, IVIG = intravenous immunoglobulins, DXM = dexamethasone, ICI $=$ immune checkpoint inhibitor. Rows highlighted in grey correspond to the cases from the prospective cohort. 